Katz, E. \& Weissbach, H. (1963). J. biol. Chem. 238, 666.

Kossel, A. \& Edlbacher, S. (1915). Hoppe-Seyl. Z. 94, 264. Linko, P., Alfthan, M., Miettinen, J. K. \& Virtanen, A. I. (1953). Acta chem. scand. 7, 1310.

Lowry, O. H., Rosebrough, N. J., Farr, A. L. \& Randall, R. J. (1951). J. biol. Chem. 193, 265.

Moore, S. \& Stein, W. H. (1948). J. biol. Chem. 176, 367.
Ratner, S., Nocito, V. \& Green, D. E. (1944). J. biol. C'hem. $152,119$.

Schmidt-Kastner, G. (1956). Naturwissenschaften, 43, 131. Sheehan, J. C., Zachau, H. G. \& Lawson, W. B. (1957). J. Amer. chem. Soc. 79, 3933.

Sivak, A., Meloni, M. L., Nobili, F. \& Katz, E. (1962). Biochim. biophys. Acta, 57, 283.

Tarr, H. L. A. (1958). Annu. Rev. Biochem. 44, 602.

Biochem. J. (1964) 90, 92

\title{
The Iodination of Ghymotrypsinogen
}

\author{
By A. N. GLAZER AND F. SANGER \\ Medical Research Council, Laboratory of Molecular Biology, Cambridge
}

(Received 25 June 1963)

The use of isotopic-labelling techniques in the determination of amino acid sequences has proved particularly valuable in connexion with the study of certain enzymes whose active centres can be specifically labelled (Cohen, Oosterbaan, Jansz \& Berends, 1959; Sanger, 1963): In this way a sequence around a single amino acid residue may be isolated and determined. Isotopic-labelling methods have the advantages that they can be applied on a very small scale, and, if appropriate techniques are used, they avoid the necessity of complete purification of a peptide provided that it can be separated from all other radioactive products. In attempts to apply these methods in a more general way with isotopic iodine we have studied the iodination of tyrosine and histidine residues in peptides and have applied the labelling technique to chymotrypsinogen.

In general, iodine should react with all tyrosine and histidine residues in a protein and it would not be expected that there would be any specific reaction, for instance at an active centre. The reactivities of different individual residues do, however, frequently vary and it may be possible to devise special ways of labelling or protecting special sites. With chymotrypsinogen it was found that an almost specific reaction was in fact obtained with one of the tyrosine residues. The present paper describes these results together with some preliminary studies on the iodination of small model peptides.

\section{MATERIALS AND METHODS}

\section{Materials}

Chymotrypsinogen (crystallized; salt-free), lot 541, and chymotrypsin (three-times crystallized), lot 6004-5, were obtained from Worthington Biochemical Corp. Monoiodohistidine and di-iodohistidine were prepared by Dr D. C.
Shaw. Chromatographically pure L-histidyl-L-alanine was given by $\mathrm{Dr} \mathrm{A}$. Patchornik. Acetyl-L-histidine was given by $\mathrm{Dr} \mathrm{A}$. Neuberger. 3-Iodo-L-tyrosine and 3,5-di-iodo-Ltyrosine were obtained from British Drug Houses Ltd. Glycyl-L-tyrosine was obtained from Roche Products Ltd. Acetyl-L-tyrosine ethyl ester was obtained from the California Corp. for Biochemical Research. Mercaptoethanol was obtained from L. Light and Co. Ltd. and was re-distilled. All other reagents used were of analyticalgrade. The ${ }^{131} \mathrm{I}$ and ${ }^{125} \mathrm{I}$ were obtained from The Radiochemical Centre, Amersham, Bucks., as carrier-free solutions of iodide in dilute sodium hydroxide, $\mathrm{pH} 8-10$, with a specific activity of $1 \mathrm{mc} / \mathrm{ml}$. Sephadex G-25 (medium grade; 100 270 mesh) was obtained from Pharmacia, Uppsala, Sweden. Streptomyces griseus protease was given by Dr M. Nomoto.

\section{Methods}

Iodination with ethanolic iodine solution. The iodine solution (either 0.1 or $0.4 \%$ ) was prepared by dissolving iodine in ethanol. A sufficient amount of carrier-free radioactive iodide was added to give a final specific activity of $1 \mu \mathrm{c} / 10 \mu \mathrm{l}$. A solution containing $0 \cdot 01-0 \cdot 1 \mu$ mole of the compound(s) to be iodinated was evaporated to dryness and redissolved in $50 \mu$ l. of aq. ammonia (sp.gr. $0 \cdot 880$ ). The appropriate amount of iodine solution was then added and the reaction allowed to proceed in a closed tube for several hours at room temperature. The reaction mixture was then evaporated to dryness either in a desiccator over $\mathrm{NaOH}$ or by evaporation in the fume-cupboard. In some cases, specified in the text, the reaction was carried out in an ice bath and stopped 30 sec. after mixing by the addition of $1 \mu$ l. of mercaptoethanol.

Iodination with iodine monochloride. A portion (0.01$0 \cdot 1 \mu \mathrm{mole}$ ) of a solution of the compound(s) to be iodinated was evaporated to dryness and redissolved in a suitable volume of $0.2 \mathrm{M}-\mathrm{Na}_{2} \mathrm{HPO}_{4}$. The solution of radioactive iodine monochloride prepared as described below was then added. The ratio of the volume of $0 \cdot 2 \mathrm{M}-\mathrm{Na}_{2} \mathrm{HPO}_{4}$ solution to that of the stock iodine monochloride solution added was always kept at 3.2:1; this proportion gave a final $\mathrm{pH}$ of 8-8.2 in the iodination mixture. Iodination was carried out at room temperature or in an ice bath and, whenever required, the reaction was stopped by the addition of mer- 
captoethanol. Iodination was also carried out at $\mathrm{pH} \mathbf{2 \cdot 4}$. This $\mathrm{pH}$ was obtained by using unbuffered stock solution of iodine monochloride. Iodination with iodine monochloride at $\mathrm{pH} 4.8$ and 6.9 was carried out in $0.2 \mathrm{M}$-ammonium acetate buffers with a ratio of the volume of buffer to that of iodine monochloride solution of $2: 1$.

Preparation and standardization of iodine monochloride solution. This solution was prepared according to the method of McFarlane (1963). The stock solution contrined $3 \cdot 3 \mu$ g.atoms of iodine $/ \mathrm{ml}$. It was stored in the cold. The efficiency of the solution varied with the age of the solution and the protein preparation used. It was therefore necessary to determine the iodinating efficiency of each solution in a preliminary experiment, by using the appropriate protein preparation.

For chymotrypsinogen, for example, this was done as follows: to $0.25 \mathrm{ml}$. of stock solution of iodine monochloride was added $5-25 \mu$ l. of carrier-free [ $\left.{ }^{131} \mathrm{I}\right]-$ or $\left[{ }^{125} \mathrm{I}\right]$ iodide, depending on the specific activity desired. After 2-3 min. at room temperature, $5 \mathrm{mg}$. of chymotrypsinogen dissolved in $0.8 \mathrm{ml}$. of $0.2 \mathrm{M}-\mathrm{Na}_{2} \mathrm{HPO}_{4}$ was added. The final $\mathrm{pH}$ of this mixture was 8 . After $15 \mathrm{~min}$. at room temperature, the reaction mixture was applied to a column $(35 \mathrm{~cm} . \times 1 \cdot 1 \mathrm{~cm}$.) of Sephadex G-25, equilibrated with $0.01 \mathrm{~N}-\mathrm{NH}_{3}$, and eluted with the same solvent. Fractions $(2 \mathrm{ml}$.) were collected and $25 \mu \mathrm{l}$. samples were counted in a Panax type D657 counter (Panax Equipment Ltd., Redhill, Surrey). The iodinating efficiency of the iodine monochloride solution was then calculated from the radioactivity (counts/min.) obtained in the protein and iodide peaks. The recovery of the radioactivity applied to the column was quantitative within experimental error.

With freshly prepared iodine monochloride solutions, the iodinating efficiency towards the chymotrypsinogen preparation used varied from 55 to $75 \%$, and towards the chymotrypsin preparation from 40 to $50 \%$.

Fractionation of iodinated peptides and amino acids. The peptides were fractionated by high-voltage paper electrophoresis as previously described (Naughton, Sanger, Hartley \& Shaw, 1960; Milstein \& Sanger, 1961). In some cases paper chromatography in butan-1-ol-acetic acidwater $(4: 1: 5$, by vol.) was found to be useful for the separation of iodotyrosine peptides.

The various iodinated model peptides were identified by comparison of their electrophoretic and chromatographic behaviour with that of authentic mono- and di-iodo derivatives of tyrosine and histidine. Identification of products of acid hydrolysis or enzymic digestion was used for further characterization. The peptides were generally located by radioautography with Ilford industrial X-ray film (type G). In a few cases experiments were carried out on a larger scale with ${ }^{127} I$, and the amino acids and peptides were located by the ninhydrin reaction.

Determination of esterase activity. The esterase activity of chymotrypsin towards acetyl-L-tyrosine ethyl ester was determined by the pH-stat method (Jacobsen, Léonis, Linderstrøm-Lang \& Ottesen, 1957). Assays were carried out at $\mathrm{pH} 8$ and $22^{\circ}$.

\section{RESULTS}

Iodination in aq. ammonia (sp.gr. 0.880). The iodination of tyrosine and histidine in concentrated ammonia solutions has been investigated by Roche,
Lissitzky, Michel \& Michel (1951). In agreement with their findings, iodination of tyrosine with an ethanolic iodine solution in aq. ammonia (sp.gr. $0 \cdot 880$ ) was found to lead to mixtures of monoiodotyrosine and di-iodotyrosine at low concentrations of iodine. In the presence of excess of iodine, only di-iodotyrosine was formed. The same behaviour was observed with peptides such as Gly-Tyr and Leu-Tyr. The tyrosine residue appeared to be stable in the presence of excess of iodine; for example, comparable amounts of Gly-di-iodo-Tyr were obtained over a range of iodine:tyrosine ratios of $4: 1$ to $20: 1$. Iodination of histidine and of histidine peptides in aq. ammonia (sp.gr. 0.880) was likewise found to give rise to monoiodohistidine and di-iodohistidine derivatives at low concentrations of iodine. In the presence of excess of iodine, the histidine derivatives were destroyed. For example, total destruction of His-Ala was observed at an iodine: His-Ala ratio of $20: 1$.

The destruction of histidine peptides by excess of iodine in ammonia could be largely prevented by carrying out the reaction in an ice bath and stopping it after 30 sec. by the addition of mercaptoethanol. Under these conditions, the main product was the mono-substituted derivative.

When mixtures of histidine and tyrosine peptides were iodinated in ammoniacal solution, both the histidine and tyrosine derivatives were formed. Somewhat greater yields of the iodotyrosine derivatives were obtained. Since these results were obtained even at low iodine:peptide ratios (e.g. $1: 10$ ), it appears that histidine and tyrosine peptides are iodinated at comparable rates under these conditions.

Iodination with iodine monochloride. On iodination of tyrosine and of tyrosine peptides with iodine monochloride no qualitative difference could be observed between reaction products at different $\mathrm{pH}$ values between $2 \cdot 4$ and $\mathbf{8 \cdot 5}$. Monoiodo- and di-iodo-tyrosine derivatives were obtained in various proportions depending on the amount of the iodinating agent used.

Iodination of histidine and histidine derivatives with iodine monochloride at $\mathrm{pH} 8$ led to the monosubstituted derivatives only. These were destroyed at iodine monochloride:histidine ratios higher than $3: 1$. No di-iodohistidine derivatives could be detected. Some protection could be achieved by carrying out the reaction in an ice bath and stopping it after 30 sec. with mercaptoethanol. Some monoiodo-His-Ala remained undestroyed under these conditions even at ratios of iodine monochloride:His-Ala of $9: 1$.

Iodination of histidine and its derivatives with iodine monochloride at $\mathrm{pH} \mathbf{2 \cdot 4}$ gave extremely low yields of the monoiodohistidine derivative. Essentially no difference could be detected between 
experiments carried out at room temperature and those performed in an ice bath and stopped after a short time by the addition of mercaptoethanol.

Some of the results obtained on iodinating tyrosine and histidine and their derivatives (as well as mixtures of these) with iodine monochloride in alkaline and acid solutions are summarized in Table 1. This Table shows that substitution of tyrosine by iodine monochloride in alkaline solution is considerably faster than that of histidine, and that in acid solution all the available iodinating agent reacts with tyrosine, no histidine derivatives being formed at all.

In work with proteins the specificity of a reagent is of paramount importance. The fact that iodine monochloride forms only one derivative (monoiodohistidine) with histidine gives it a considerable advantage over iodine in ammonia where two derivatives (monoiodo- and di-iodo-histidine) are found. For this reason and because of the milder conditions we have preferred to use iodine monochloride for the studies on chymotrypsinogen.

Exchange reactions. The exchange reaction between iodine and di-iodotyrosine at room temperature in aqueous solution was first reported by Miller, Anderson, Madison \& Salley (1944) and used subsequently by other workers for the preparation of radioactive di-iodotyrosine (Tong, Taurog \& Chaikoff, 1954). In the present work it was found that interchange occurs readily between iodine monochloride or iodine and iodinated derivatives of histidine as well as those of tyrosine. The interchange occurred over the $\mathrm{pH}$ range $2 \cdot 4-8 \cdot 5$ for iodine monochloride, and over this $\mathrm{pH}$ range and in aq. ammonia (sp.gr. 0.880 ) for iodine. The results are summarized in Table 2. The interchange reaction proceeds at a rate comparable with that of direct substitution of histidine or tyrosine.

Partial acid hydrolysis of iodinated peptides. Partial acid hydrolysis, in $6 \mathrm{~N}-\mathrm{hydrochloric}$ acid at $105^{\circ}$ in unevacuated tubes, of iodotyrosine peptides, which had been eluted from paper, led to variable, considerable and, occasionally, quantitative loss of the label. On the other hand, satisfactory recoveries of iodohistidine peptides were obtained under these conditions. Partial acid hydrolysis of iodinated tyrosine and histidine peptides with $12 \mathrm{~N}$-hydrochloric acid at $37^{\circ}$ gave excellent yields of the split products.

Migration of label in strongly acid solution was not observed in any of the experiments performed. For example, hydrolysis of $1 \mu \mathrm{g}$. of Gly-di-[131 I]iodo-Tyr in the presence of either $0.6 \mathrm{mg}$. of trypsin or $0.4 \mathrm{mg}$. of conalbumin with constantboiling hydrochloric acid at $105^{\circ}$ for $1 \mathrm{hr}$. gave the same labelled products both in the presence and absence of added protein, these products being monoiodotyrosine, di-iodotyrosine, Gly-monoiodoTyr and Gly-di-iodo-Tyr (Fig. 1). No transfer of label to any of the tyrosine peptides arising from the proteins added could be detected. Similar results were obtained on prolonged partial acid hydrolysis in $12 \mathrm{~N}$-hydrochloric acid at $37^{\circ}$.

The addition of sodium [ $\left.{ }^{131} \mathrm{I}\right]$ iodide to tyrosine, monoiodotyrosine or di-iodotyrosine in hydro-

\section{Table 1. Iodination of tyrosine and histidine and their derivatives with iodine monochloride} under various conditions

Details are given in the text. The amount of each reactant is given in $\mu$ moles in parentheses. The approximate relative amounts of radioactive products formed are indicated by the numbers of + signs in parentheses.
Reaction conditions
Reactants
$\mathrm{pH} 8\left(0 \cdot 15 \mathrm{M}-\mathrm{Na}_{2} \mathrm{HPO}_{4}\right)$
His $(0 \cdot 1)+\mathrm{ICl}(0 \cdot 08)$
His $(0 \cdot 05)+\operatorname{Tyr}(0 \cdot 05)+\operatorname{ICl}(0 \cdot 08)$
$\operatorname{Tyr}(0 \cdot 1)+\operatorname{ICl}(0 \cdot 08)$
Acetyl-His (0.05) + Gly-Tyr (0.05) + IC] $(0.08)$
His-Ala $(0 \cdot 05)+$ Gly-Tyr $(0 \cdot 05)+$ ICl $(0 \cdot 08)$
pH $2 \cdot 4$ (unbuffered solution) $\mathrm{His}(0 \cdot 1)+\mathrm{ICl}(0 \cdot 08)$
Gly-Tyr $(0 \cdot 1)+\operatorname{ICl}(0 \cdot 08)$
His $(0 \cdot 05)+$ Gly-Tyr $(0 \cdot 05)+\mathrm{ICl}(0 \cdot 08)$
Acetyl-His (0.05) + Gly-Tyr (0.05) + ICl $(0.08)$
Acetyl-His $(0 \cdot 1)+\mathrm{ICl}(0 \cdot 08)$
His-Ala $(0 \cdot 1)+\operatorname{ICl}(0 \cdot 08)$
His-Ala $(0.05)+$ Gly-Tyr $(0.05)+$ ICl
$(0.08)$
Radioactive products
Monoiodo-His $(++++)$
Di-iodo-Tyr $(++++)$, monoiodo-Tyr
$(++)$, monoiodo-His (trace)
Di-iodo-Tyr $(++++)$, monoiodo-Tyr
$(++++)$
Gly-di-iodo-Tyr $(++++)$, Gly-monoiodo-
Tyr $(++++)$, acetylmonoiodo-His (trace)
Gly-di-iodo-Tyr $(++++)$, Gly-monoiodo-
Tyr $(++++)$, monoiodo-His-Ala $(+)$
Monoiodo-His (trace)
Gly-di-iodo-Tyr $(++++)$, Gly-monoiodo-
Tyr $(++++)$
Gly-di-iodo-Tyr $(++++)$, Gly-monoiodo-
Tyr $(+++)$
Gly-di-iodo-Tyr $(++++)$, Gly-monoiodo-
Tyr $(+++)$
Acetylmonoiodo-His (trace)
Monoiodo-His-Ala $(+++)$
Gly-di-iodo-Tyr $(++++)$, Gly-monoiodo-
Tyr $(+++)$ 
Table 2. Exchange of iodine between iodine, iodine monochloride and iodinated tyrosine and histidine and their derivatives under various conditions

Details are given in the text. The amount of each reactant is given in $\mu$ moles in parentheses. The approximate relative amounts of radioactive products formed are indicated by the numbers of + signs in parentheses.

Reaction conditions

Ethanolic ammonia (sp.gr. 0.880)

Ethanolic ammonia (sp.gr. 0.880)

Ethanolic ammonia (sp.gr. $\mathbf{0 \cdot 8 8 0}$ )

Ethanolic ammonia (sp.gr. 0·880)

Ethanolic ammonia (sp.gr. 0.880)

Ethanolic ammonia (sp.gr. 0.880)

pH 2.4 (unbuffered solution) pH 4.8, pH 6.9 (ammonium acetate buffers) pH $8\left(\mathrm{Na}_{2} \mathrm{HPO}_{4}\right)$

pH $2 \cdot 4$ (unbuffered solution) pH 2.4 (unbuffered solution) pH $8\left(\mathrm{Na}_{2} \mathrm{HPO}_{4}\right)$
Reactants

Di-iodo-Tyr $(0 \cdot 1)+{ }^{181} \mathrm{I}_{2}(0 \cdot 2)$

Mono[ ${ }^{131}$ I] ]odo-Tyr $(0 \cdot 1)+I_{2}(0 \cdot 4)$

Di-iodo-His $(0 \cdot 1)+{ }^{181} I_{2}(0 \cdot 2)$

Gly-Tyr (0.1) + di-iodo-Tyr (0.1) + ${ }_{131} I_{2}(0 \cdot 2)$

His $(0 \cdot 1)+$ di-iodo-Tyr $(0 \cdot 1)+{ }^{131} I_{2}(0 \cdot 04)$

His-Ala $(0 \cdot 1)+$ di-iodo-Tyr $(0 \cdot 1)+$ ${ }^{181} \mathrm{I}_{2}(0 \cdot 04)$

Di-iodo-Tyr $(0 \cdot 1)+{ }^{181} \mathrm{ICl}(0 \cdot 08)$

Monoiodo-His $(0 \cdot 1)+{ }^{181} \mathrm{ICl}(0 \cdot 08)$

Di-iodo-His $(0 \cdot 1)+{ }^{181} \mathrm{ICl}(0 \cdot 08)$
Radioactive products

Di-[ ${ }^{131}$ I] iodo-Tyr $(++++)$

Di-[131I]iodo-Tyr (trace)

Di-[131I] iodo-His $(++++)$

Gly-di-[ ${ }^{131}$ I] iodo-Tyr $(++++)$,

di-[181I]iodo-Tyr $(+++)$

Mono[131I]iodo-His $(++++)$, di-

[ ${ }^{131}$ I] iodo-His $(+)$, di-[181I]iodo-Tyr $(++)$

Mono[ ${ }^{131}$ I] iodo-His-Ala $(++++)$, di-

[131I]iodo-His-Ala (+), di-[ $\left.{ }^{131} \mathrm{I}\right]$ iodo-Tyr $(++)$

Di-[131I]iodo-Tyr $(++++)$

Mono[131I]iodo-His $(++++)$

Di-[131I]iodo-His $(++++)$

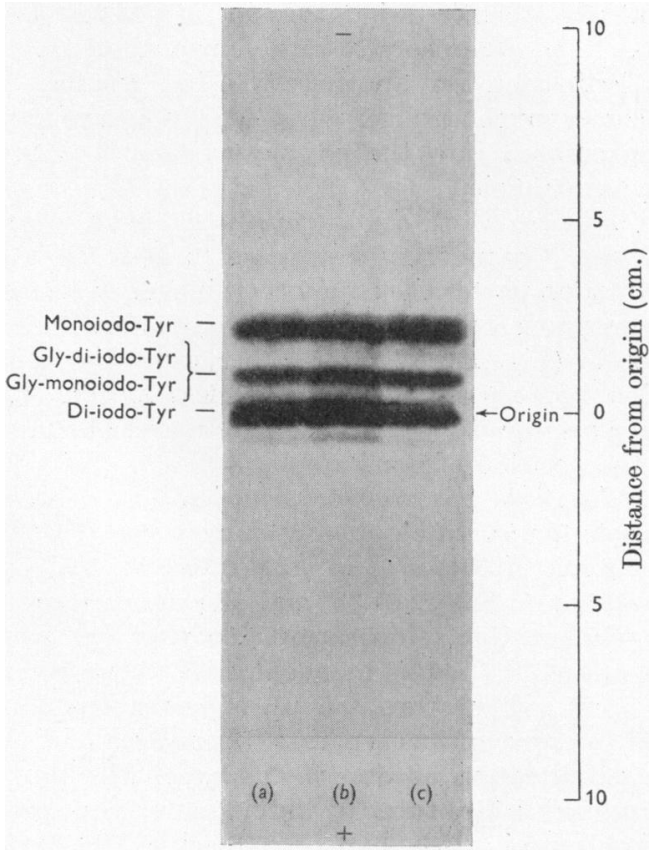

Fig. 1. Radioautograph obtained after ionophoresis (pH $6.5 ; 40 \mathrm{v} / \mathrm{cm}$.; $2 \mathrm{hr}$.; Whatman no. 52 paper) of Gly-di-iodoTyr hydrolysed: $(a)$ in the presence of trypsin; $(b)$ in the presence of conalbumin; $(c)$ in the absence of added protein. Details are given in the text.

chloric acid, with subsequent heating at $105^{\circ}$ for $60 \mathrm{~min}$., resulted in a barely detectable uptake of 131I into tyrosine and its iodo derivatives. These results are in contrast with the observations of
Sanger \& Thompson (1963) on the ready bromination of tyrosine on acid hydrolysis in the presence of bromide.

Iodination of chymotrypsinogen. Chymotrypsinogen was iodinated with various amounts of iodine monochloride to give preparations containing from 0.5 to $2 \mathrm{~g}$.atoms of iodine/mole of protein. The extent of iodination was checked as described above by passing the mixture through Sephadex G-25. The desalted protein was either freeze-dried or evaporated to dryness over sodium hydroxide.

The dried material was taken up in a small volume $(0.2 \mathrm{ml} . / 4 \mathrm{mg}$.) of concentrated hydrochloric acid and placed at $37^{\circ}$ for $24 \mathrm{hr}$. The acid was then removed over sodium hydroxide, and after re-wetting and drying down twice, the material was applied to either Whatman no. 52 or $3 \mathrm{MM}$ paper and subjected to electrophoresis at pH 3.5. The pattern obtained is shown in Fig. 2.

The label appeared to be localized almost entirely in band $A$ (Fig. 2). Elution followed by rehydrolysis of the material from band $A$ with $12 \mathrm{~N}$-hydrochloric acid at $37^{\circ}$ for $48 \mathrm{hr}$. gave, on electrophoresis at $\mathrm{pH} 3 \cdot 5$, only material indistinguishable in its mobility from band $A$ and material running in the position of band $C$ (Fig. 2).

The material running in the position of band $A$ was purified by successive electrophoreses at pH $6.5,2.0$ and 8.9 , followed by descending chromatography in butan-1-ol-acetic acid-water. It appeared to be homogeneous in each of the above systems and is referred to below as peptide $A$. After the four-step purification the peptide was eluted and hydrolysed for $20 \mathrm{hr}$, with $6 \mathrm{~N}$-hydrochloric acid at $105^{\circ}$, and the amino acids in the hydrolysate were identified by comparison with 
controls on electrophoresis at pH 2. The hydrolysate contained threonine, arginine and traces of tyrosine.

Digestion of labelled peptides with $S$. griseus protease proved extremely useful for the identification of the amino acid carrying the label: in particular, it made possible a ready differentiation between peptides containing monoiodotyrosine and those containing di-iodotyrosine. In a large number of peptides isolated from enzymic and partial acid hydrolysates of labelled proteins, the $S$. griseus protease released the labelled amino acid quantitatively. An amount of peptide $A$ containing $0.01 \mu \mathrm{C}$ of ${ }^{131} \mathrm{I}$ was dissolved in $25 \mu \mathrm{l}$. of $0.02 \mathrm{M}$ ammonium carbonate and incubated with $2 \mu \mathrm{g}$. of $S$. griseus protease for $14 \mathrm{hr}$. at $37^{\circ}$. The digest was subjected to electrophoresis at pH 2. Only one radioactive product was obtained which was indistinguishable from the di-iodotyrosine control.

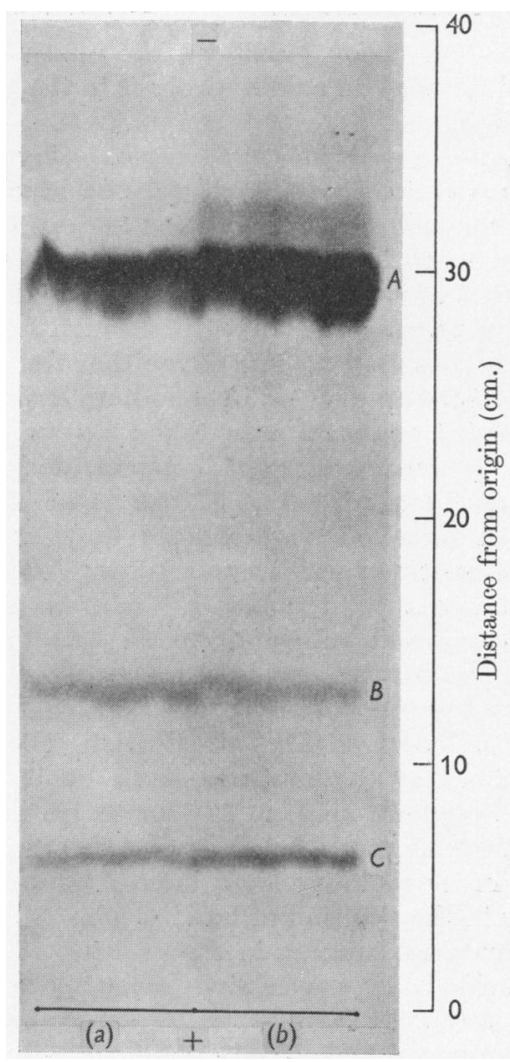

Fig. 2. Radioautograph obtained after ionophoresis (pH 3.5 ; 52 v/cm.; $90 \mathrm{~min}$.; Whatman $3 \mathrm{MM}$ paper) of partial acid hydrolysates of: $(a){ }^{131}$ I-labelled chymotrypsin and (b) ${ }^{131}$ I-labelled chymotrypsinogen, containing 0.7 and 1.7 g.atoms of iodine/mole respectively. Details are given in the text.
Peptide $A$ was treated with periodate as described by Naughton et al. (1960). The periodate-treated peptide was acidic at $\mathrm{pH} 6 \cdot 5$, whereas peptide $A$ is basic at this pH. This indicates that the $N$ terminal amino acid of peptide $A$ is a hydroxy amino acid and the sequence is therefore Thr(Arg, di-iodo-Tyr).

A sample of peptide $A$ was subjected to the Edman degradation as described by Naughton et al. (1960). The product was basic and indistinguishable from peptide $A$ on electrophoresis at pH 6.5 and 3.5 . It could, however, be readily separated from peptide $A$ by chromatography in butan-1-ol-acetic acid-water in which it moved faster. After two successive degradations the radioactivity appeared almost entirely in a band identified as di-iodotyrosine on electrophoresis at pH 2.0.

The above information is consistent with the sequence Thr-Arg-di-iodo-Tyr for peptide $A$.

Band $C$ (Fig. 2) was identified as di-iodotyrosine by comparison of its electrophoretic mobility with that of authentic di-iodotyrosine at $\mathrm{pH} \mathrm{2,3.5}$ and 6.5. Band $B$ appears to represent a small amount of iodination on another tyrosine residue and becomes much stronger when the amount of iodine incorporated into the chymotrypsinogen exceeds 2 g.atoms/mole.

Comparison of chymotrypsinogen with chymotrypsin. Chymotrypsin appears to give the same iodination pattern as chymotrypsinogen at levels of incorporation of approx. 1 g.atom of iodine/mole of protein (Fig. 2). With chymotrypsin, the iodination appears to be somewhat less specific, since there appears to be slightly more material running in the position of band $B$.

Iodination of chymotrypsinogen in urea. A sample (5 mg.) of chymotrypsinogen was dissolved in $0.8 \mathrm{ml}$. of $10 \mathrm{M}$-urea in $0.2 \mathrm{M}$-disodium hydrogen phosphate, $\mathrm{pH} 8 \cdot 2$, at $37^{\circ}$ and allowed to stand for $10 \mathrm{~min}$. at this temperature. To this was added $0.2 \mathrm{ml}$. of [ $\left.{ }^{131} \mathrm{I}\right]$ iodine monochloride. After $10 \mathrm{~min}$. at room temperature, $0.5 \mathrm{ml}$. of water was added and the protein was separated from urea and salts by gel-filtration as described above. The protein contained $1.6 \mathrm{~g}$.atoms of iodine/mole. The freezedried protein was hydrolysed with $12 \mathrm{~N}$-hydrochloric acid at $37^{\circ}$ for $22 \mathrm{hr}$. and then subjected to electrophoresis at pH 3.5 (Fig. 3). A much more complex pattern was obtained, indicating that the iodination is more random on the denatured protein.

Activity of chymotrypsin after iodination with iodine monochloride. Iodination of chymotrypsin with small amounts of iodine monochloride at room temperature led to some loss in activity. Incorporation of 2 g.atoms of iodine $/ \mathrm{mole}$ was associated-with approx. $20 \%$ loss of activity 


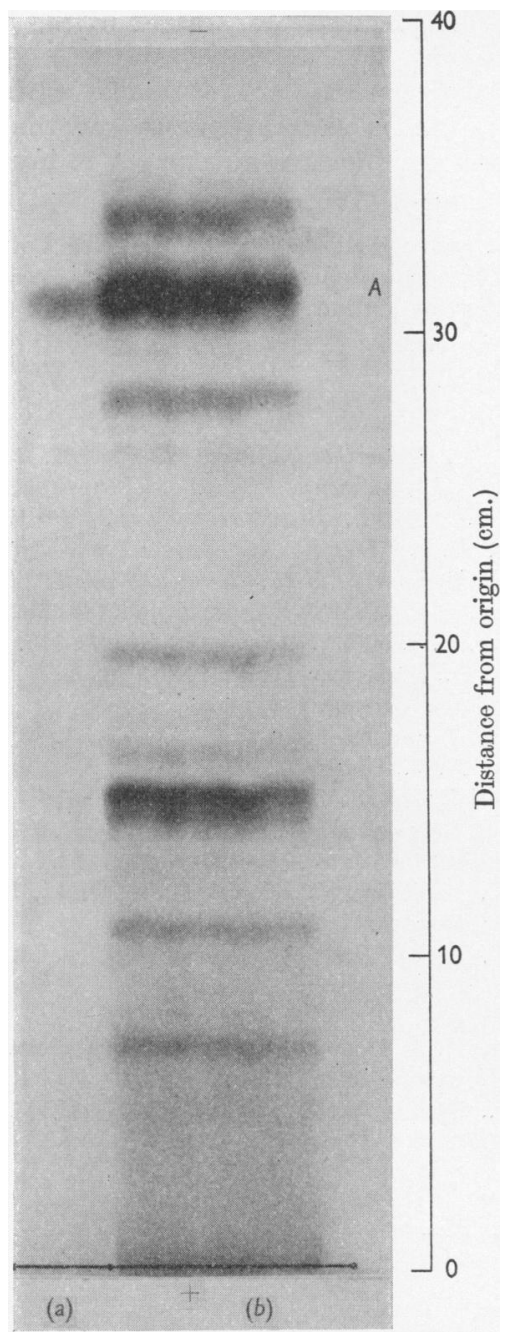

Fig. 3. Radioautograph obtained after ionophoresis ( $\mathrm{pH}$ 3.5 ; $52 \mathrm{v} / \mathrm{cm}$.; 90 min.; Whatman $3 \mathrm{MM}$ paper) of $(b)$ partial acid hydrolysate of urea-denatured ${ }^{131}$ I-labelled chymotrypsinogen containing 1.6 g.atoms of iodine/mole, compared with that of $(a){ }^{131}$ I-labelled peptide $A$ marker. Details are given in the text.

towards acetyl-L-tyrosine ethyl ester (Table 3). Examination of partial acid patterns of chymotrypsin preparations containing $2 \cdot 1,2 \cdot 6$ and $3.9 \mathrm{~g}$.atoms of iodine $/$ mole indicated that, at these levels of incorporation, iodination of at least two additional tyrosine residues/molecule is taking place. The patterns obtained with preparations containing 2.6 and 3.9 g.atoms of iodine $/ \mathrm{mol} \Theta$ respectively were very similar, indicating that the additional groups were iodinated at comparable rates.
Table 3. Inactivation of chymotrypsin during iodination with iodine monochloride at room temperature

Details are given in the text.

$\begin{array}{cc}\begin{array}{c}\text { Iodine } \\ \text { incorporated } \\ \text { (g.atoms/mole }\end{array} & \begin{array}{c}\text { Inactivation } \\ \text { of enzyme) }\end{array} \\ 0.5 & 3 \\ 1 \cdot 0 & 7 \\ 1 \cdot 1 & 9 \\ 2 \cdot 0 & 29 \\ 2 \cdot 2 & 16 \\ 3 \cdot 1 & 29 \\ 4 \cdot 28 & 78 \\ 5 \cdot 3 & 95 \\ 6 \cdot 6 & 100\end{array}$

\section{DISCUSSION}

The results presented above indicate that in native chymotrypsinogen (and chymotrypsin) one of the four tyrosine residues/molecule is so situated that it reacts with iodine monochloride considerably more rapidly than the remaining three residues. That this difference in reactivity is, in fact, dependent on the native conformation of the protein is clearly demonstrated by the random distribution of iodine among the tyrosine residues when the iodination is carried out in concentrated urea solution. From the available sequence work on chymotrypsinogen and chymotrypsin (Hartley, 1962), it is possible to assign the peptide Thr-ArgTyr to the $C$-terminal position of the $B$ chain in chymotrypsin. The split leading to the conversion of $\delta$-chymotrypsin into $\alpha$-chymotrypsin takes place at this tyrosine residue. The fact that the bond adjoining this tyrosine is the only one cleaved during the autolysis of $\delta$-chymotrypsin indicates that this residue must be readily available to the enzyme and is, presumably, on the surface of the molecule. This view is consistent with its preferential iodination. Some inactivation (approx. $20 \%$ ) of chymotrypsin preparations, containing 2 g.atoms of iodine/mole, was observed. This inactivation does not, however, seem to be related to the substitution on the readily iodinatable residue (see Table 3). It is well known (McFarlane, 1958) that iodine monochloride is a strong oxidizing agent and it seems possible that the inactivation observed is due to a slow oxidation reaction occurring simultaneously with the substitution. The oxidation of a single readily-oxidizable methionine residue has been shown to inactivate chymotrypsin (Ray, Latham, Katsoulis \& Koshland, 1960; Schachter \& Dixon, 1962). That oxidtion reactions undoubtedly take place is indicated by the comparatively low efficiency (approx. $45 \%$ ) of iodination of chymotrypsin by iodine monochloride under the conditions employed. 
The ready detection of the rapidly iodinatable tyrosine residue in chymotrypsinogen and the elucidation of the sequence adjoining this residue demonstrate the applicability of radiochemical methods to peptides and proteins labelled with ${ }^{131} \mathrm{I}$ or ${ }^{125} \mathrm{I}$.

In control experiments it was found that diiodotyrosine is only slowly deiodinated in concentrated hydrochloric acid at $37^{\circ}$, whereas monoiodotyrosine is largely deiodinated under these conditions. Thus, in $16 \mathrm{hr}$. at $37^{\circ}$ at an iodotyrosine concentration of $0.5 \mu \mathrm{mole} / \mathrm{ml}$. of concentrated hydrochloric acid, di-iodotyrosine was deiodinated to the extent of less than $5 \%$, and monoiodotyrosine to the extent of $75 \%$. This presumably accounts for the absence of monoiodotyrosine derivatives in the chymotrypsinogen hydrolysis.

The occurrence of exchange reactions somewhat limits the scope of the method for the study of active-centre sequences.

\section{SUMMARY}

1. The iodination of tyrosine, histidine and their simple peptides with iodine in ammonia and with iodine monochloride has been studied by using radioactive iodine.

2. With iodine in ammonia mono- and di-iodo derivatives are formed with both residues, whereas with iodine monochloride histidine is converted only into the monoiodo derivative.

3. Treatment of the non-radioactive iodo derivatives with radioactive iodine leads to the incorporation of the label by exchange reactions.

4. Iodination of native chymotrypsinogen with iodine monochloride occurs preferentially at one tyrosine residue which is present in the sequence Thr-Arg-Tyr.

5. Similar results are obtained with native chymotrypsin. The substitution on the readily iodinatable residue does not appear to involve loss in enzymic activity.

A.N.G. held a Fellowship from the Jane Coffin Childs Memorial Fund for Medical Research, which also aided this investigation by a grant.

\section{REFERENCES}

Cohen, J. A., Oosterbaan, R. A., Jans7, H. S. \& Berends, F. (1959). J. cell. comp. Physiol. 54 (Suppl. 1), 231.

Hartley, B. S. (1962). Brookhaven Symp. Biol. 15, 85.

Jacobsen, C. F., Léonis, J., Linderstrøm-Lang, K. \& Ottesen, M. (1957). Meth. biochem. Anal. 4, 171.

McFarlane, A. S. (1958). Nature, Lond., 182, 53.

McFarlane, A. S. (1963). J. clin. Invest. 42, 346.

Miller, W. H., Anderson, G. W., Madison, R. K. \& Salley, D. J. (1944). Science, 100, 340.

Milstein, C. \& Sanger, F. (1961). Biochem. J. 79, 456.

Naughton, M. A., Sanger, F., Hartley, B. S. \& Shaw, D. C. (1960). Biochem. J. 77, 149.

Ray, W. J., Latham, H. G., jun., Katsoulis, M. \& Koshland, D. E. (1960). J. Amer. chem. Soc. 82, 4743.

Roche, J., Lissitzky, S., Michel, O. \& Michel, R. (1951). Biochim. biophys. Acta, 7, 439.

Sanger, F. (1963). Proc. chem. Soc., Lond., p. 76.

Sanger, F. \& Thompson, E. O. P. (1963). Biochim. biophys. Acta, 71, 468.

Schachter, H. \& Dixon, G. H. (1962). Biochem. biophys. Res. Commun. 9, 132.

Tong, W., Taurog, A. \& Chaikoff, I. L. (1954). J. biol. Chem. 207, 59.

Biochem. J. (1964) 90, 98

\title{
Studies on Metabolism of Vitamin A
}

\section{DIETARY PROTEIN CONTENT AND METABOLISM OF VITAMIN A*}

\author{
BY D. S. DESHMUKH, P. MALATHI AND J. GANGULY \\ Department of Biochemistry, Indian Institute of Science, Bangalore 12, India
}

(Received 19 March 1963)

Dzialoszynski, Mystkowski \& Stewart (1945) showed that vitamin A was present in human blood as a protein complex and not in the colloidal state. This idea was further extended by Ganguly, Krinsky, Mehl \& Deuel (1952) and by Ganguly \& Krinsky (1953), who suggested that a specific carrier protein probably maintained a steady

* Part 4: Mahadevan, Seshadri Sastry \& Ganguly (1963). vitamin $\mathbf{A}$ alcohol concentration in the blood. Also, Krinsky, Cornwell \& Oncley (1958) have shown that vitamin $\mathbf{A}$ alcohol and vitamin $\mathbf{A}$ ester are transported by two separate lipoproteins in human blood.

Some recent observations have, however, focused attention on the coincidence of widespread protein malnutrition and vitamin A deficiency in human beings in many parts of the world, and have led to 